\title{
Microsoft paint imaging system - a photogrammetric approach to fragmentation measurement in rock and aggregate production
}

\author{
Thomas B. Afeni ${ }^{1 \bowtie(1)}$, Emmanuel O. Okeleye ${ }^{1^{*}}$ \\ ${ }^{1}$ Federal University of Technology, Akure, 340001, Nigeria \\ *Corresponding author: e-mail emmanokeleye@gmail.com, tel. +2349068939545
}

\begin{abstract}
Purpose. To evaluate the fragment sizes of blasted material using Microsoft paint imaging system. It focuses on digital imaging fragmentation analysis of rocks and aggregates using the Microsoft paint, putting into consideration, the camera's specifications to define the fragment size.
\end{abstract}

Methods. Five blast tests were conducted in the field to examine the effectiveness of this method of fragmentation analysis and also investigate the influence of burden, spacing and specific charge on degree of fragmentation.

Findings. The particle size distribution obtained from Microsoft-paint imaging analysis shows that the mean run-off-mine sizes are $0.6,0.58,0.42,0.36$ and $0.54 \mathrm{~m}$, and the average boulder sizes of fragmented particles are $1.19,1.11,0.93,0.81$ and $1.03 \mathrm{~m}$, for blast test 1 , blast test 2, blast test 3 , blast test 4 and blast test 5 respectively. Blast test 1 produced the highest boulder size of $1.15 \mathrm{~m}$ followed by blast test 2 while blast test 4 has the minimum boulder size. The results also shows that with increasing burden and spacing distances, the mean run-off-mine size, average boulder particle size increased. As expected, the mean run-off-mine size, average boulder size also decreased as specific charge increases.

Originality. The results of this research can be compared to fragmentation analysis using analytical software such as Wipfrag, Blastfrag, Fragscan, Powersieve, e.t.c.

Practical implications. Microsoft paint imaging system can be used as a fragmentation analytical tool. Thus, results of the fragmentation analysis can be used for better decision making in future blast designs of a mine.

Keywords: digital imaging, fragmentation, resolution effect, blast shot designs, boulders, particle size distribution

\section{Introduction}

Fragmentation means the process of breaking the solid in situ rock mass into several smaller pieces capable of being excavated or handled by material handling equipment. Breakage of rock mass is done by conventional drilling and blasting operation which is the most important method of fragmentation in almost all quarries. There are a number of controllable and uncontrollable parameters that govern the fragmentation of rock. The controllable parameters can be controlled by designing an effective and efficient blast and use of appropriate explosive for blasting. While the uncontrollable parameters as the name suggests cannot be controlled, but certain measures have to be taken to minimize the effects of these parameters in rock blasting in order to have an optimum rock fragment [1], [2].

In open pit mining, where blasting is employed for excavation, the overall cost effectiveness of the production operations is compatible with optimization of drilling and blasting parameters. Thus, the ultimate goal of a blasting engineer in a mine is to achieve a muck pile having a suitable size distri- bution of the rock that can be efficiently loaded, transported and milled [3].This goal can be achieved by examining the relationship between blast design parameters and fragmentation achieved. Also, it is extremely important to make the connection between rock blasting results and their impact on the downstream operations cost. Spathis [4][5] discussed factors that affect size reduction and its influence on mineral liberation, which mainly described the area of prediction and assessment together with the related assumptions: fines, mean size, oversize, cumulative size distributions, and measurement protocol.

\subsection{Optimum fragmentation}

The rock fragmentation obtained as an outcome of blasting operations is said to be optimum, when it contains a maximum percentage of fragments in the desired range of size capable of being moved by material handling equipment. The Desired size usually means the size that is demanded and can be effectively utilized by the consumers for further operations without further processing. The desired size for different consumers is different. For example, 
the size of dolomite fragments required for railway tracks is comparatively smaller than the coarser ones those used by a cement industry [6].

Effective blast design for optimum fragmentation of rock is a control blasting method used to limit over-break of the rock, production of fines, reduce fractures within remaining rock walls and ground vibrations etc., after blasting in a mine. Blasting is the predominant method of fragmentation of consolidated in-situ mineral deposit. In recent times, the use of explosives and the public related problems have increased greatly as a result of consumption of explosives in increasing quantities, thus the use of explosive considering the deposit, hardness of the mineral deposit, texture, dimension of spacing and burden etc., are necessary to have an effective blasting design for optimum fragmentation of rocks [1], [7].

Moreover, it is necessary to adopt an effective blasting method such as line drilling, trim blasting, smooth blasting, pre-splitting and the use of modern blasting technology which would give the required optimum fragmentation. A method of improving rock fragmentation with explosives based on a new way of explosion energy transfer in the solid media provides a high efficiency by changing the gas dynamic processes of the expansion of detonation products in the charge chamber.

\subsection{Rock fragmentation analytical methods}

Rock fragmentation distribution can be assessed in a number of ways. These methods vary from those that are very simple to perform and qualitative to the impractically difficult in production situations, but quantitatively accurate. Fragmentation can be evaluated qualitatively on a shot to shot basis by blaster observation and loader operator feedback about sizing and diggability. This method lacks data and is subject to a significant amount of bias and human error. Sieving of shot rock is a very accurate quantitative method of determining fragmentation size, but it is time consuming, impractical, and expensive in active mining operations. Digital image analysis provides a middle ground between the previous methods with a quantitative measure of fragmentation sizing that is not disruptive to the mining process, and is therefore a practically applicable method of obtaining fragmentation results of mine blasts. Digital image analysis of shot rock can be performed using images of the muckpile taken with handheld/portable cameras, with belt mounted systems, or loader mounted systems [8].

There are various software packages and image capture systems designed to facilitate digital image analysis for fragmentation sizing. These include WipFrag, Split, PortaMetrics, GoldSize, Fragscan, PowerSieve, and Blastfrag [8][11]. Many of the image analysis systems operate in a similar manner and most require some type of scaling item to be placed in the photo. For example, WipFrag takes the image of a muckpile or other broken rock and converts that image into a net of rock fragments. This net is measured and used to provide a sieve simulation of the fragments. This provides fragmentation statistics, such as the D10, mean, D50, and D90, and graphs of the fragmentation sizing [12]. WipFrag [12] states that, "images must be clear, evenly lit and must be acquired systematically in order to minimize errors and optimize results accuracy". Even when using high quality photos, rock outline editing is typically necessary to define fragments, identify fines, and identify shadow or other areas to be excluded from the analysis. Systematic photo acquisi- tion is important both immediately after the shot and throughout the mucking process to ensure all areas of interest are accounted for in the photogrammetric analysis. Photos must be collected throughout blasting and mucking operation to eliminate the sampling error and bias caused by the typically more coarse fragmentation found on the surface of muck piles [2], [11].

However, this research discovers a relatively quick and efficient digital imaging analytical method. It focuses on digital imaging fragmentation analysis of rock and aggregate using the Microsoft paint, putting into consideration the camera's design and nomenclature to define the fragment size.

\subsection{Aims and objective of study}

The aim of this paper to highlight the importance of fragmentation analysis in mines and also give an efficient fragmentation analytical method that could be used in place of expensive and inaccessible analytical software packages.

The objectives of the study are:

- to evaluate the fragment sizes of blasted rock material using Microsoft paint imaging system as an analytical tool;

- determine the effect of burden, spacing and specific charge on fragment size; and to predict rock fragment size using Microsoft office paint as an analytical tool.

\section{Methodology of research}

Five test blasts were conducted on an active blast face of a granite quarry. The test blasts were full-size production shots conducted between May 16, 2017 and August 22, 2017. The tests included all shots on this bench during this timeframe. Each blast shot has approximately 3200-4000 cubic meters of rock. After each blast shot, digital Photographs were taken systematically for each blast design immediately after each blast shot for analysis to obtain particle size distribution (run-off-mine sizes, boulder sizes) of blast result. The digital pictures were subjected to resolution analysis based on some parameters and design properties of the camera to obtain the fragment size of each blast shot design.

The capacity of the front end loader was used to define the fragmentation size, the front end loader has a bucket which has a capacity to handle fragments of $0.64 \mathrm{~m}$, therefore fragments which has size greater than $0.68 \mathrm{~m}$ which cannot be handled by the front end loaders are considered as boulders thus requires secondary blasting while those below are considered as run-off-mine. The various blast designs tested are summarized in Table 1, while Figure 1 shows the connection pattern for all the blast shot tested.

Table 1. Various blast designs for different blast shot tested

\begin{tabular}{lccccc}
\hline $\begin{array}{c}\text { Blast design } \\
\text { parameters }\end{array}$ & $\begin{array}{c}\text { Blast } \\
\text { test 1 }\end{array}$ & $\begin{array}{c}\text { Blast } \\
\text { test 2 }\end{array}$ & $\begin{array}{c}\text { Blast } \\
\text { test 3 }\end{array}$ & $\begin{array}{c}\text { Blast } \\
\text { test 4 }\end{array}$ & $\begin{array}{c}\text { Blast } \\
\text { test 5 }\end{array}$ \\
\hline Spacing (M) & 4.0 & 3.0 & 3.0 & 2.5 & 2.5 \\
Burden (M) & 4.0 & 3.0 & 3.0 & 3.0 & 3.0 \\
Hole depth (M) & 27.0 & 27.0 & 27.0 & 27.0 & 27.0 \\
Height of bottom charge & 4.0 & 3.2 & 4.0 & 3.2 & 3.2 \\
Height of column charge & 22.5 & 23.3 & 22.5 & 23.3 & 21.5 \\
Stemming & 3.5 & 3.5 & 3.5 & 3.5 & 5.0 \\
Bottom charge (KG) & 9 & 7 & 9 & 7 & 7 \\
Column charge (KG) & 160 & 160 & 170 & 160 & 140 \\
Drilling pattern & \multicolumn{5}{c}{ Rectangular } \\
Charging device & \multicolumn{5}{c}{ Nonel } \\
Initiation device & \multicolumn{5}{c}{} \\
\hline
\end{tabular}




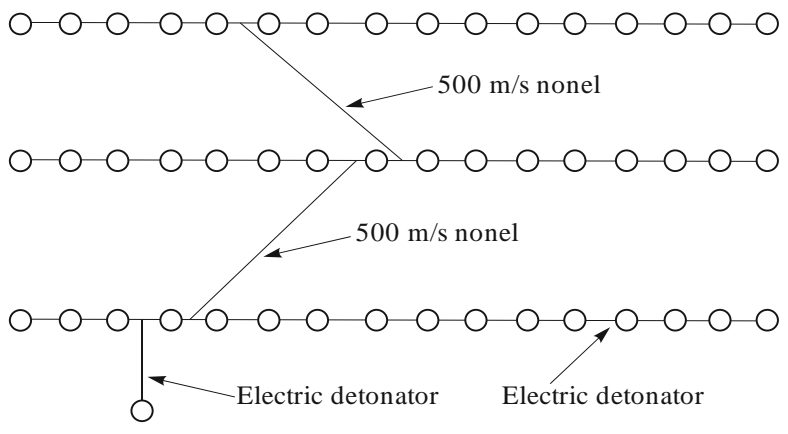

Figure 1. Connection pattern of blast shot

\subsection{Resolution analysis of digital imaging}

Camera specification designs and nomenclature are essential tools in the analysis of fragment size in digital imaging. The focal length, pixel size, and the distance of the camera from the object are the major constraint that defines the fragment size. Firstly, the distance of the camera from muckpile is determined; this can be used to determine the cameras field of view based on the horizontal distance between the camera and the area of muckpile of interest taking height into consideration. The difference between the original horizontal distance and the real distance becomes more dramatic as the height of the camera or muckpile goes up. The actual (Slope) distance can be determined using the Pythagorean Theorem as shown in Figure 2.

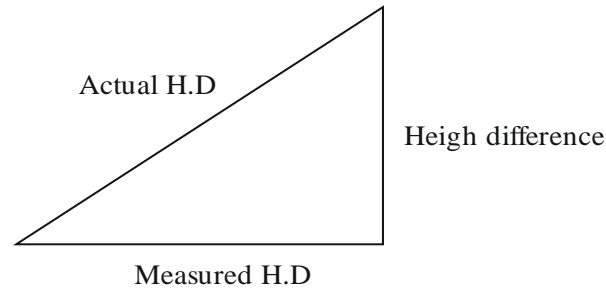

Figure 2. Relationship between height difference and actual horizontal distance and measured horizontal distance

$A h D^{2}=M h D^{2}+H D^{2}$,

where:

$A h D$ - the actual or slope distance between the camera and the area of the muckpile;

$M h D$ - the measured horizontal distance between the camera and area of the muckpile;

$H D$ - the height difference between the camera setup and the height of the muckile.

Thus the size of each fragment can be evaluated from Equation 2 below:

$A f s=\frac{F h \cdot P s \cdot A h d}{F l}$,

where:

$A f s$ - the actual fragment size;

$F h$ - fragment size in digital image;

$P s$ - pixel size of the camera;

Ahd-actual distance of the camera from the area of the muck pile;

$F l$ - focal length of the camera.

However, for the purpose of carrying out this research, a measured horizontal distance of $15 \mathrm{~m}$ was maintained from the camera to the muck pile area. A camera of focal length of $24 \mathrm{~mm}$ and a pixel size of $13 \mathrm{mp}$ is used in this research.

\section{Results}

The particle sizes for each blast shot were analyzed pictorially using Microsoft-paint imaging system and correcting into original size by magnification scale factor and camera design resolution to obtain the particle sizes distribution (runoff-mine sizes and boulder sizes) for each blast shot design.

\subsection{Blast test 1}

Figure 3 shows the fragmentation distribution of particles in the blast test 1 . This blast shot produced fragment mainly boulders which may requires further secondary blasting to enhance handling by material handling equipment.

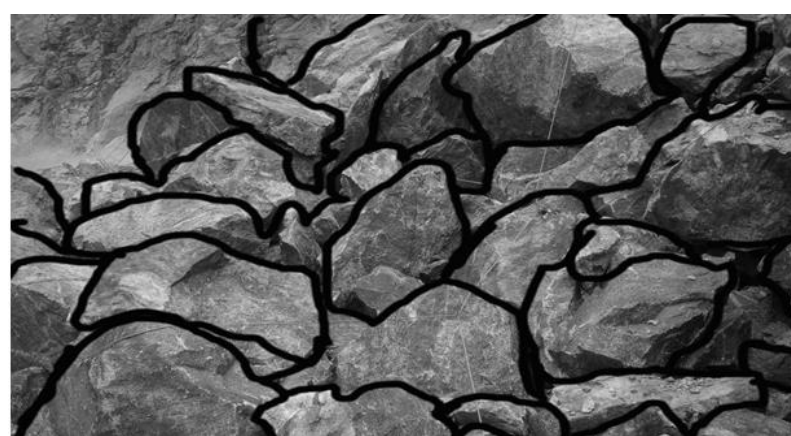

Figure 3. Fragmentation distribution of blast test 1 (generated using Microsoft-paint)

The sizes of each fragment of the blast test 1 were obtained by Microsoft paint to obtain the particle distribution as shown in Table 2.

Table 2. Fragment size of boulders and run-off-mine in blast shot 1

\begin{tabular}{ccc}
\hline S/N & Fragment size $(\mathrm{m})$ & Status \\
\hline 1 & 1.11 & Boulder \\
2 & 1.32 & Boulder \\
3 & 1.07 & Boulder \\
4 & 1.33 & Boulder \\
5 & 0.64 & Run-off-mine \\
6 & 0.72 & Boulder \\
7 & 0.54 & Run-off-mine \\
8 & 0.59 & Run-off-mine \\
9 & 0.63 & Run-off-mine \\
10 & 1.32 & Boulder \\
11 & 1.67 & Boulder \\
12 & 1.04 & Boulder \\
13 & 1.09 & Boulder \\
14 & 0.45 & Run-off-mine \\
15 & 1.21 & Boulder \\
\hline
\end{tabular}

The average boulder size and mean run-off-mine size in blast design 1 is estimated to be $1.19 \mathrm{~m}$ and $0.6 \mathrm{~m}$ respectively.

\subsection{Blast test 2}

Figure 4 shows the fragmentation distribution of particles in the blast test 2 .

The fragmentation sizes of blast test 2 as obtained from Microsoft paint are shown in the Table 3.

The average boulder size and the mean run-off size in blast test 2 are estimated to be $1.11 \mathrm{~m}$ and $0.58 \mathrm{~m}$ respectively.

\subsection{Blast test 3}

Figure 5 shows the fragmentation distribution of particles in the blast test 3 .

The fragmentation sizes of blast test 3 as obtained from Microsoft paint are shown in the Table 4. 


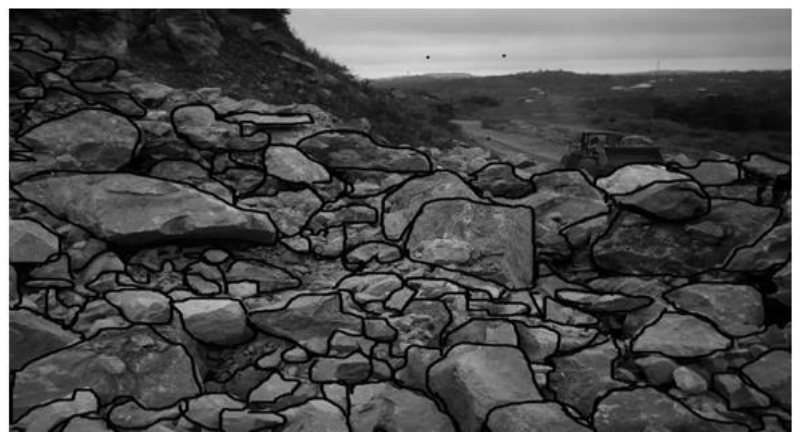

Figure 4. Fragmentation distribution of blast test 2 (generated using Microsoft-paint)

Table 3. Fragment size of boulders and run-off-mine in blast shot 2

\begin{tabular}{ccc}
\hline S/N & Fragment size $(\mathrm{m})$ & Status \\
\hline 1 & 0.79 & Boulder \\
2 & 1.32 & Boulder \\
3 & 0.96 & Boulder \\
4 & 0.64 & Run-off-mine \\
5 & 1.19 & Boulder \\
6 & 0.72 & Boulder \\
7 & 0.58 & Run-off-mine \\
8 & 0.62 & Run-off-mine \\
9 & 0.57 & Run-off-mine \\
10 & 0.44 & Run-off-mine \\
11 & 1.43 & Boulder \\
12 & 0.63 & Run-off-mine \\
13 & 1.56 & Boulder \\
14 & 0.59 & Run-off-mine \\
15 & 0.87 & Boulder \\
\hline
\end{tabular}

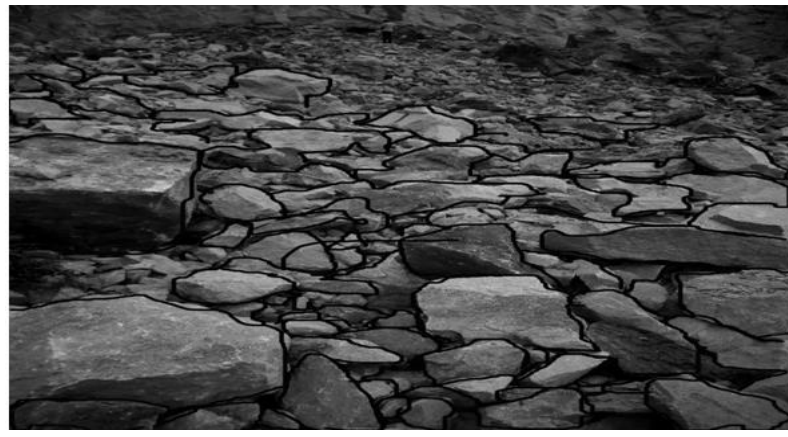

Figure 5. Fragmentation distribution of blast test 3 (generated using Microsoft-paint)

Table 4. Fragment size of boulders and run-off-mine in blast shot 3

\begin{tabular}{ccc}
\hline S/N & Fragment size $(\mathrm{m})$ & Status \\
\hline 1 & 1.03 & Boulders \\
2 & 1.12 & Boulders \\
3 & 0.46 & Run-off-mine \\
4 & 0.47 & Run-off-mine \\
5 & 0.37 & Run-off-mine \\
6 & 0.53 & Run-off-mine \\
7 & 0.32 & Run-off-mine \\
8 & 0.43 & Run-off-mine \\
9 & 0.77 & Boulders \\
10 & 0.49 & Run-off-mine \\
11 & 0.57 & Run-off-mine \\
12 & 0.48 & Run-off-mine \\
13 & 0.28 & Run-off-mine \\
14 & 0.54 & Run-off-mine \\
15 & 0.20 & Run-off-mine \\
\hline
\end{tabular}

The average boulder size and the mean run-off-mine size in blast design 3 are estimated to be $0.93 \mathrm{~m}$ and $0.42 \mathrm{~m}$ respectively.

\subsection{Blast test 4}

Figure 6 shows the fragmentation distribution of particles in the blast test 4 . Fragmentation result of blast shot 4 is considered to be optimal because it produces particle which can be easily be loaded by front end loader, thus which contains minimal number of boulders.

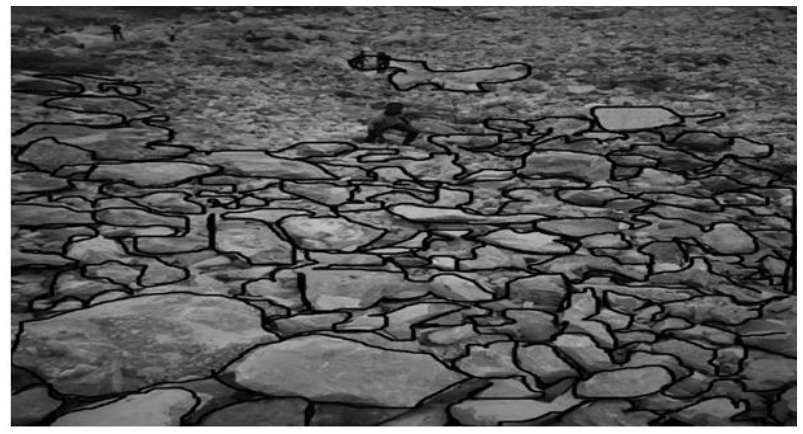

Figure 6. Fragmentation distribution of blast test 4 (generated using Microsoft-paint)

The fragmentation sizes of blast test 4 as obtained from Microsoft paint are shown in the Table 5.

Table 5. Fragment size of boulders and run-off-mine in blast shot 4

\begin{tabular}{ccc}
\hline S/N & Fragment size & Status \\
\hline 1 & 0.92 & Boulder \\
2 & 0.74 & Boulder \\
3 & 0.40 & Run-off-mine \\
4 & 0.35 & Run-off-mine \\
5 & 0.46 & Run-off-mine \\
6 & 0.40 & Run-off-mine \\
7 & 0.48 & Run-off-mine \\
8 & 0.33 & Run-off-mine \\
9 & 0.42 & Run-off-mine \\
10 & 0.32 & Run-off-mine \\
11 & 0.56 & Run-off-mine \\
12 & 0.26 & Run-off-mine \\
13 & 0.14 & Run-off-mine \\
14 & 0.54 & Run-off-mine \\
15 & 0.76 & Boulder \\
\hline
\end{tabular}

The average boulder size and the mean run-off-mine sizes in blast design 4 are estimated to be $0.81 \mathrm{~m}$ and $0.36 \mathrm{~m}$ respectively.

\subsection{Blast test 5}

In order to obtain the particle size, pictures of muck piles were taken after blasting to obtain the particle distribution. Figure 7 shows the fragmentation distribution of particles in the blast test 5 .

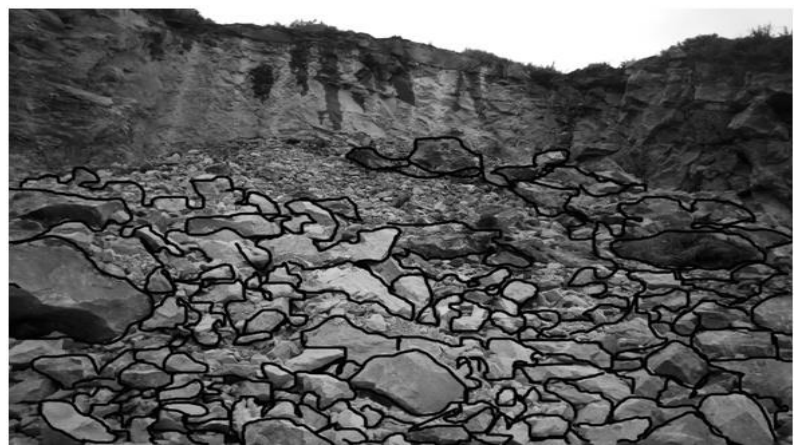

Figure 7. Fragmentation distribution of blast test 5 (generated using Microsoft-paint) 
The fragmentation sizes of blast design 5 as obtained from Microsoft paint are shown in the Table 6 below.

Table 6. Fragment size of boulders and run-off-mine in blast shot 5

\begin{tabular}{ccc}
\hline S/N & Fragment size & Status \\
\hline 1 & 0.98 & Boulders \\
2 & 1.02 & Boulders \\
3 & 1.06 & Boulders \\
4 & 0.66 & Run-off-mine \\
5 & 0.54 & Run-off-mine \\
6 & 0.44 & Run-off-mine \\
7 & 0.52 & Run-off-mine \\
8 & 0.55 & Run-off-mine \\
9 & 0.67 & Run-off-mine \\
10 & 0.48 & Run-off-mine \\
11 & 1.04 & Boulder \\
12 & 0.61 & Run-off-mine \\
13 & 0.37 & Run-off-mine \\
14 & 1.09 & Boulder \\
15 & 0.97 & Boulder \\
\hline
\end{tabular}

The average boulder size and the mean run-off-mine sizes in blast design 5 are estimated to be $1.03 \mathrm{~m}$ and $0.54 \mathrm{~m}$ respectively.

The average maximum (boulder) sizes and average mean particle sizes of various blast designs that were tested as shown in blast test 1 to 5 in Table 2 to 6 are summarized in Table 7.

Table 7. Fragment size distributions of blast design 1-5

\begin{tabular}{ccc}
\hline Blast shots & $\begin{array}{c}\text { Mean run-off } \\
\text { mine size }(\mathrm{m})\end{array}$ & $\begin{array}{c}\text { Average boulder } \\
\text { size }(\mathrm{m})\end{array}$ \\
\hline Blast shot 1 & 0.60 & 1.19 \\
Blast shot 2 & 0.58 & 1.11 \\
Blast shot 3 & 0.42 & 0.93 \\
Blast shot 4 & 0.36 & 0.81 \\
Blast shot 5 & 0.54 & 1.03 \\
\hline
\end{tabular}

From the table above, blast shot 1 has the highest mean run-off-mine size $(0.60 \mathrm{~m})$ and average boulder size $(1.19 \mathrm{~m})$, while blast shot 4 has the lowest mean run-off-mine size and average boulder size of 0.36 and 0.81 respectively. It is noted that the mean run-off-mine size and average boulder sizes decreases as the burden and spacing of blast design (maintained at the same specific charges) decreases as observed in comparison of blast result of blast shot 1,2 , and 4 . It is also noted that increase in specific charge of blast hole design (maintained at the burden and spacing) result to lower mean run-off-mine size and average boulder size and vice versa as observed in comparison of blast result of blast shot 2 and 3; and also blast shot 4 and 5 .

\subsection{Limitations of digital image analytical method}

There are a few problems associated with digital image analysis methods that should be understood when utilizing them for fragmentation optimization, but that do not negate the usefulness of the analysis. These include the manual editing of rock outlines to ensure correct delineation of fragments. This introduces human error into the analysis, especially when particle sizes are small. In images with larger particle size or where the image resolution is high, this error is minimized. Other issues include errors associated with the calculations used to transform digital measurement into rock surface measurements, the limitations of the resolution of image systems, shape effects causing fragments to be assigned mesh sizes differently in the image analysis than they would be in sieving, and density assumptions. When utilizing image analysis, some of these problems, such as the volume calculations, are irrelevant because any error introduced will apply to all of the images and the difference in size distribution from photo to photo will still be evident. Additionally, despite the issues, when tested, the size distributions found using digital image analysis of muckpiles matches those of the sieved material well. Coarse materials tend to result in fewer errors than fine materials [10].

\section{Conclusions}

The research examines the use of digital imaging analysis method to predict the fragment sizes of blasted material using the Microsoft paint imaging system. In order to achieve the objective of this research, five blast shots were conducted in the field to consider the effect of a specific charge and geometry in bench blasting and particle sizes of blasted rocks were estimated by Microsoft-paint digital imaging analysis method.

The particle size distribution obtained from Microsoftpaint imaging analysis show that, the mean run-off-mine sizes are $0.6 \mathrm{~m}, 0.58 \mathrm{~m}, 0.42 \mathrm{~m}, 0.36 \mathrm{~m}$, and $0.54 \mathrm{~m}$, and the average boulder sizes of fragmented rocks are $1.19 \mathrm{~m}$, $1.11 \mathrm{~m}, 0.93 \mathrm{~m}, 0.81 \mathrm{~m}, 1.03 \mathrm{~m}$, for blast test 1, blast test 2, blast test 3, blast test 4 and blast test 5 respectively. Blast test 1 produced the highest boulder size of $1.19 \mathrm{~m}$ followed by blast test 2 while blast test 4 has the minimum boulder size. The result shows that with increasing burden and spacing distances, the mean run-off-mine size and the average boulder particle size increased. The mean run-of-mine size, average boulder size also decreased as specific charge increases.

The cost of aggregate production in a quarry has a minimum value at an optimum fragmentation size. Prediction and evaluation of fragmentation degree will help mining engineers in selecting blasting parameters to produce required material size at a known cost and also in selecting other crushers and conveyor systems. Optimum fragmentation size may not be the required size but knowing the size distribution for particular blast and rock mass conditions, the Mining engineer can adapt and modify the blasting if possible.

\section{Acknowledgements}

The authors appreciate staff and management of ZIBOFM quarry, Akure, Ondo state, Nigeria, for their cooperation during data collection for this research.

\section{References}

[1] Raina, A.K., Choudhury, P.B., Ramulu, M., Chrakraborty, A.K., \& Dudlankar, A.S., (2002). Fragalst - an indigenous digital image analysis system for grain size measurement in mines. Journal of Geologic Scientist, 561-569.

[2] Afeni, T.B., Onifade, M., Aladejare, A., \& Okeleye, E.O. (2020). Effective blast design for optimum fragmentation of rock (A case study of ZIBO-FM quarry, Akure, Ondo state). Manuscript submitted for publication in SAJ.

[3] Singh, P.K., Roy, M.P., Paswan, R.K., Sarim, M.D., \& Suraj, K. (2005). Blast design and fragmentation control-key to productivity. Dhanbad, India: Central Institute of Mining and Fuel Research, $18 \mathrm{p}$.

[4] Spathis, A.T. (2002). A brief review of blasting effects on comminution and mineral liberation. Orica Technical Report No. 58561, Kurri Kurri, Australia.

[5] Spathis, A.T. (2009). Formulae and techniques for assessing features of blast - induced fragmentation distributions. In Proceedings $9^{\text {th }}$ International Symposium on Rock Fragmentation by Blasting FRAGBLAST-9 (pp. 209-219). Granada, Spain. 
[6] Maerz, N.H., Franklin, J.A., \& Rothenburg, L. (1987). Measurement of rock fragmentation by digital analysis. $6^{\text {th }}$ congress of ISRM, 1-14

[7] Hettinger, T. (2015). A system for the estimation of fragmentation after production blasts. Rotterdam, (1996), 67-71.

[8] Motion metrics. (2015). Portable analysis PortaMetrics. Retrieved from http://www.motionmetrics.com/potable

[9] Split engineering. (2015). Split-desktop software. Retrieved from http://www.spliteng.com/product/splitdesktop-software
[10] Sanchidrián, J.A., Segarra, P., Ouchterlony, F., \& López, L.M. (2008). On the accuracy of fragment size measurement by image analysis in combination with some distribution functions. Rock Mechanics and Rock Engineering, 42(1), 95-116. https://doi.org/10.1007/s00603-007-0161-8

[11] Johnson, P., \& Catherine, E. (2014). Fragmentation analysis in the dynamic stress wave collision regions in bench blasting. Theses and Dissertation (Mining engineering), $16 \mathrm{p}$.

[12] WipFrag. (2015). WipFrag manual. North Bay, Ontario, Canada, 5-32.

Система створення зображення Microsoft - фотограмметричний підхід до вимірювання гранулометричного складу при видобутку породи і щебню

Томас Б. Афені, Еммануель О. Окелі

Мета. Оцінка гранулометричного складу зруйнованої вибухом гірської породи із використанням системи створення зображень зображення Microsoft.

Методика. Були проведені п'ять вибухових випробувань в польових умовах гранітного кар'єру для підтвердження ефективності даного методу гранулометричного аналізу та вивчення впливу лінії найменшого опору (ЛНО), відстані між шпурами і певного заряду на ступінь дроблення. Гранулометричний склад визначався із використанням сервісу Мicrosoft за авторською методикою. Гранулометричний аналіз цифрового зображення породи та щебню із використанням сервісу Microsoft здійснено 3 урахуванням технічних характеристик камери, які дозволяють визначати розмір шматків.

Результати. Розподіл обсягів частинок, отриманий за допомогою аналізу зображень Microsoft, показує, що середній розмір частинок, що розлетілися, дорівнює $0.60,0.57,0.43,0.39$ і 0.55 м, при цьому середній розмір великих уламків дорівнює $1.15,1.07,0.97$, 0.83 і 1.02 м для 1, 2, 3, 4 і 5 вибуху відповідно. Визначено, що при першому вибуху були отримані найбільші уламки розміром 1.15 м, трохи менші - під час третього вибуху, і найменші - під час четвертого вибуху. Результати випробувань свідчать, що при збільшенні ЛНО та відстані між шпурами середній розмір частинок, що розлетілися, і середній розмір великих уламків збільшується, і зменшується при збільшенні окремо взятого заряду.

Наукова новизна. Надано оцінку гранулометричного складу підірваної породи із використанням сервісу Microsoft i встановлено, що метод можна порівняти з гранулометричним аналізом, виконаним за допомогою Wipfrag, Blastfrag, Fragscan, Powersieve, та характеризується достатньою достовірністю.

Практична значимість. Система створення зображень Microsoft може бути використана як інструмент гранулометричного аналізу. Результати гранулометричного аналізу будуть сприяти прийняттю більш ефективних рішень при проектуванні вибухових робіт на шахтах в майбутньому.

Ключові слова: цифррові зображення, гранулометричний склад, ефект розширення, проекти вибухових робіт, валуни, розподіл розмірів частинок

\section{Система создания изображений Microsoft - фотограмметрический подход к измерению гранулометрического состава при добыче породы и щебня}

Томас Б. Афени, Эммануэль О. Окели

Цель. Оценка гранулометрического состава горной породы с использованием системы создания изображений Microsoft.

Методика. Были проведены пять взрывных испытаний в полевых условиях гранитного карьера для подтверждения эффективности данного метода гранулометрического анализа и изучения влияния линии наименьшего сопротивления (ЛНС), расстояния между шпурами и определенного заряда на степень дробления. Гранулометрический анализ цифрового изображения породы и щебня с использованием сервиса Microsoft произведен с учетом технических характеристик камеры, которые позволяют определять размер кусков.

Результаты. Распределение размеров частиц, полученное при помощи анализа изображений Microsoft, показывает, что средний размер разлетевшихся частиц равен $0.60,0.57,0.43,0.39$ и 0.55 м, при этом средний размер крупных обломков равен $1.15,1.07,0.97$, 0.8 и 1.02 м для 1, 2, 3, 4 и 5 взрыва соответственно. Определено, что при первом взрыве были получены самые крупные обломки размером 1.15 м, немного меньшие - во время третьего взрыва, и наименьшие - во время четвертого взрыва. Результаты испытаний свидетельствуют, что при увеличении ЛНС и расстояния между шпурами средний размер разлетевшихся частиц и средний размер крупных обломков увеличивается, и уменьшается при увеличении отдельно взятого заряда.

Научная новизна. Дана оценка гранулометрического состава взорванной породы с использованием сервиса Microsoft и установлено, что метод сопоставим с гранулометрическим анализом, выполненным при помощи Wipfrag, Blastfrag, Fragscan, Powersieve, и характеризуется достаточной достоверностью.

Практическая значимость. Система создания изображений Microsoft может быть использована как инструмент гранулометрического анализа. Результаты гранулометрического анализа будут способствовать принятию более эффективных решений при проектировании взрывных работ на шахтах в будущем.

Ключевые слова: цифровые изображения, гранулометрический состав, эффект разрешения, проекты взрывных работ, валуны, распределение размеров частиц

\section{Article info}

Received: 29 October 2019

Accepted: 3 June 2020

Available online: 25 June 2020 